\title{
Design of experiment with emphasis on intuitive use
}

\author{
Caio Márcio Almeida e Silva ${ }^{\text {a, }}$, Maria Lúcia R. L. Okimoto ${ }^{\mathrm{b}}$ \\ a'Departament of Design, Federal University of Paraná, caiomarcio1001@yahoo.com.br, General Carneiro street, \\ 460, Dom Pedro I Building, $8^{\text {th }}$ floor, Curitiba - PR, Brazil. \\ ${ }^{\mathrm{b}}$ Deparment of Machanical Engineering, Federal University of Paraná, lucia.demec@ufpr.br, Polytechnic Center, \\ Garden of Americas, Curitiba - PR, Brazil.
}

\begin{abstract}
The article presents a step in the design of an experiment that has an emphasis on the following research question: how to assess the user friendliness of products in use? For this purpose, we developed three different approaches involving the use of products in intuitiveness. In this table, were removed some information regarding the positive aspects. These were broken down into procedures to be performed for an experiment with the same scope.
\end{abstract}

Keywords: Design, design of experiment, intuitive use, usability

\section{Introduction}

This article attempts to summarize the experimental knowledge of intuitive use for the design practice. Thus, we present three-to policies carried out for the experimental structure of intuitive knowledge in product design. The design of the experiment is allocated after the literature review and analysis of similar-logical method. We try to apply the theory in this way for construction to make the analysis of the experiment.

The primary purpose of the experiment is to provide a familiarization with the practice of experiments involving people, products and from the standpoint of user friendliness in interaction. Specific objectives are: addressing the use of intuitiveness in different ways in order to guide the final experiment, performing a literature review to identify relevant issues, and gain experience with the tabulation and data processing to apply objectively and clear in the final experiment, and finally present a discussion relating the tabulated data and treated with those found in the literature.
From the analysis of the experiments was built a table that presents an overview of the experiments. In this structure also tried to point out some positive and negative aspects of the experiments and that should be considered in an experiment involving the use of intuitive products. These aspects are intended to guide professionals to design experiments, and in order to seek answers the following research question: how to assess the user friendliness of products in use?

\section{Methodological formulation}

Three experiments were developed, named A, B and $\mathrm{C}$. The experiment deals with the recognition and the trial of a product that was not known by individuals. The experiment $\mathrm{B}$ is the recognition of the functions of a product previously presented. C The experiment deals with the perception of a product from solely a sensory stimulus.

The experiments required different techniques for extraction and analysis of data. So the choice of

\footnotetext{
${ }^{*}$ Corresponding author. E-mail: editorial@iospress.nl. Check if the checkbox in menu Tools/Options/Compatibility/Lay out footnotes like Word 6.x/95/97 is selected if you make a footnote for the corresponding author.
} 
statistical parameters for the different experiments according to previously defined goal.

\section{Experiment}

\subsection{Experiment " $A$ "}

Table 1: Summary of experiment A.

Title $\begin{aligned} & \text { Considering the intuitive use of products: the } \\ & \text { case Juicy Salif }\end{aligned}$

\begin{tabular}{ll}
\hline Objective (s) & $\begin{array}{l}\text { Check the recognition of Salif Juicy with } \\
\text { and without the presentation of the product. } \\
\text { Compare the trial of the product before and } \\
\text { after use. }\end{array}$
\end{tabular}

\begin{tabular}{ll}
\hline $\begin{array}{l}\text { Object used in the } \\
\text { experiment }\end{array}$ & Juicy Salif \\
\hline instrumental & $\begin{array}{l}\text { Cups, the Juicy Salif juicer orange, oranges } \\
\text { cut in half matches, odorizers environments, } \\
\text { a plastic container. }\end{array}$
\end{tabular}

Number of 20 subjects

participants

\begin{tabular}{ll}
\hline Metrics & $\begin{array}{l}\text { Performance metrics (success of the task and } \\
\text { errors) and Self-report }\end{array}$
\end{tabular}

$\begin{array}{ll}\text { statistical } & \text { Chi-square } \\ \text { treatment }\end{array}$

treatment

SOURCE: Author (2011).

\section{Procedure:}

The experiment was divided into three stages described below:

In the first stage the participants were invited to be positioned in front of the product. Each subject performed the experiment separately. The product was covered by a black casing. Participants were asked to withdraw the black casing and the product are observed. They were then asked the following questions:

\section{- Have you ever seen this product?}

The evaluation was made from the binary "known lunknown".

\section{-What product is this?}

There was a time set for the response. Some participants failed to respond with a possible product. So I asked him to suggest at least one product in response.

The evaluation of this phase was done initially with the binary "right $\backslash$ wrong". Like most of the answers were not correct, it was decided to divide them into categories according to their own answers. Still in the first stage, was made the following question:

\section{- What is the function of this product?}

The evaluation was made exactly like the previous question: binary "squeeze fruit $\backslash$ other" and categories of responses. As an indicator of this first step, we have the appearance of the product.

In the second step, the mediator explains the experiment on the product, highlighting its role as "orange juicer". Then was made the following question:

- How would be used this product? Justify your answer indicating the product.

In this question it was necessary to indicate the location of product functionality.

Until then, most participants had not even touched the product. So, we asked for them to seek the answer by using visual stimuli as well as the tactile stimuli. Yet, with this incentive, some participants still sought to keep a certain distance from the object.

The assessment of this question was asked by the moderator with the aid of an illustration of the juicer. At this stage the participants indicated the parts of the product, which were marked in the illustration by the moderator.

Even at this stage, it was offered the orange and a cup. It was asked the participant to perform the task to squeeze the orange using the technique of thinking aloud.

The evaluation of this task was based on performance and time. In performance, we consider the ideal place to put the orange and the glass. At the time, we consider the time taken to start the task. So, instead of putting the exact time, divide it into three groups: 
Time $=$ small $(1$ to 59 seconds $)$

Time $=$ medium $(60$ to 119 seconds $)$

Time $=$ large $($ over $120 / 2)$

This task was to indicate the function of the resource, how it works.

In the third step, we presented the concepts of practical function, aesthetic and symbolic function of Lobach (2001), described as follows:

\section{Practical function}

"These are products which are practical for all the physiological aspects of use. (...) Through the practical functions of a chair to meet the physiological needs of the user, facilitating the body to assume a position to prevent fatigue. "Lobach (2001, p.58)

\section{Aesthetic function}

"The aesthetic function is the relationship between a product and a user-level sensory processes. (...) The aesthetic function of the products is a psychological aspect of sensory perception during their use.

"Lobach (2001, p.59)

\section{Symbolic function}

"A product has a symbolic function when the spirituality of man is stimulated by the perception of this object, to establish links with their previous experiences and sensations. (...) The symbolic function of products is determined by all the spiritual, psychological and social use. "Lobach (2001, p.64)

The meanings require a greater repertoire in the design area, decided to present three other definitions of our own, seeking a more direct communication and a little more colloquial.

Practical function: connected directly to the practical functionality of the object.

Aesthetic function, linked directly to the aesthetic and formal aspects, such as color, shape and texture. Symbolic function, directly linked to the symbolism, the issues present in our repertoire. Next, we asked participants to identify the predominant function of the orange squeezer Juicy Salif.

\section{Considerations:}

During the experiment, we found that most participants did not seek the formal setting, the evidence for the operation of the product. The same was achieved only when the product was made, or when the moderator prompted them. More positively identified: the use of the art "thinking aloud", extremely useful for a qualitative assessment, seek a product is not known for participants (may also do the opposite: seeking participants who do not know the product to be tested ). On the negative side, we have: the inadequacy of space to the type of experiment, since it was far from a water point, the presentation of the product by the mediator, and not treatment planning data prior to application of the experiment

\subsection{Experiment $B$}

Table 2: Summary of experiment B.

\begin{tabular}{ll}
\hline Title & Assessment of product from the intuition \\
\hline Objective (s) & $\begin{array}{l}\text { Checking the recognition of the functions of } \\
\text { a product already presented to the user. }\end{array}$ \\
\hline $\begin{array}{l}\text { Object used in the } \\
\text { experiment }\end{array}$ & Cursor pointer with wireless \\
\hline $\begin{array}{l}\text { instrumental } \\
\text { Number of } \\
\text { participants }\end{array}$ & $\begin{array}{l}\text { Cursor pointer with wireless, notebook, } \\
\text { mechanical engineering) }\end{array}$ \\
\hline Metrics & Performance (success of the task and errors) \\
\hline $\begin{array}{l}\text { statistical } \\
\text { treatment }\end{array}$ & Descriptively \\
\hline
\end{tabular}

SOURCE: Author (2011).

Procedure:

Population to be sampled - ten participants were selected to detect problems and get reliable measurements. To this end, we chose people who work at the Academy.

Data to be collected - The desired data were presented as statements of tasks. In all, seventeen. Thus, it was clear standard and what should be done.

The tasks were as follows:

... plug the receiver into the computer (USB port); ... call the pointer;

... connect the receiver until the green lights on it (to synchronize);

... press the "connect" the pointer until the green light turns off the receiver (the pointer to synchronize with the receiver);

... activate the "mouse"; 
... open the show "Bionic";

... place the slides in full screen (rotating the presentation);

... activate the "host";

... point the laser at the black banner in front that is slides forward until the slide "Example: lotus effect (video)";

... activate the "mouse" when you get to slide

"Example: lotus effect" (video);

... Click on the picture that is on the slide "Example: lotus effect" to access the video. Once you start playing the video, go to the next task;

... activate the "host";

... point the laser at the black banner in front; ...advance the slides until the end of the presentation; activate the "mouse";

... close the Power Point program and warn that it has completed the tasks.

Desired degree of accuracy - was chosen tarpresented a verbal explanation and visual (with the help of four slides) about the product. Participants would also count with a schematic drawing of the product with the names and functions of key tasks were not pre-set time to get things done. The dynamic test showed the following: product presentation and implementation of tasks set.

Measurement - Measurement was made from the observation of sessions for members and filming, and then the support of the following metrics: success of the task, task time and observation of overt behaviors and coding.

Referral system - Two members observed the interaction of users with products and completed a three protocol tab of verbal behaviors and nonverbal.

Select Sample - The sample was selected from professionals who work at the University. Among them, we chose individuals who frequently work with expository multimedia presentations as teachers, doctoral, masters and masters.

Pretest - were made four pre-tests. Among them, the team that conducted the test enhanced and rewrote some of the listed tasks to be performed.

Organization of the experiment - A room dedicated to the experiment had a table and chair, the product evaluated (Mouse Pointer), a notebook, a card with the schematic design of the pointer, a questionnaire and a pencil. In front of the participant, was a black banner. And on the right diagonal of the participant, had a camcorder. Once the subject entered in the testing room, they received the instructions, and signed an informed consent about the research. The subjects also signed the permission of the shooting test. After this step, the test was performed with the product. After the end of the test subjects answered a questionnaire. Thereby ending the test. The average time of testing was fifteen minutes. For data analysis we developed a framework describing: the tasks, the success of the task, aspects that influence the intuitiveness of use, and the incidence of the visual search for schemes product functions. So the evaluation of the intuitiveness took from the aspects described in Table 2. These were measured from performance metrics, with the help of usability testing, the technique of verbalization and observation.

\section{Considerations:}

During the experiment, we found that most participants did not seek in the form of the product references of possible operation of the product. This relationship was only achieved only when the product was presented, or when they were helped by the moderator. As we identify positive aspects: the use of technology: the use of technology "thinking aloud" (extremely useful for a qualitative assessment); action strategy - seeking a product not known to participants (may also do the opposite: seeking participants who do not know the product to be tested). The negative aspects presented were: the inadequacy of space to the type of experiment (since the site was far from a water point), the presentation of the product by the mediator, and the selection of the statistical method for the different experiments occurred only after the application of the experiment.

\subsection{Experimento $C$}


Table 3

Summary of experiment C.

\begin{tabular}{ll}
\hline Title & $\begin{array}{l}\text { Product perception from sensory stimuli: the } \\
\text { case of vacuum cleaner. }\end{array}$ \\
\hline Objective (s) & $\begin{array}{l}\text { The identification of elements of the product } \\
\text { from one of the sensory stimuli. Once } \\
\text { tabulated data for each mode, to identify } \\
\text { which stimulus provided a clearer } \\
\text { recognition about the product. }\end{array}$ \\
\hline $\begin{array}{ll}\text { Object used in the } \\
\text { experiment }\end{array}$ & $\begin{array}{l}\text { vacuum cleaner -Consul } \\
\text { instrumental }\end{array}$ \\
\hline vetrics & Protection. \\
\hline SOURCE: Authormance (success of the task and errors)
\end{tabular}

SOURCE: Author (2011).

Procedure:

The experiment $\mathrm{C}$ was divided into four stages: a general step that was common to all three groups of experiments and a specific step further, with emphasis on each sensory stimulus and a second final step also common to the three groups.

Participants were divided into three groups. The first group was directed from the interaction of visual stimuli, the second group was directed from the interaction of auditory stimuli, and the third group was directed from the interaction of tactile stimuli. After this interaction the subjects were asked to complete the following information:

\section{Step 1:}

\section{General}

1 - Describe accurately and in detail what you saw and felt when interacting with the product.

2 - In your opinion, you could identify the product from this interaction?

$$
\text { ( ) Yes ( ) No }
$$

3 - Which product did you just interact?

Indicator for items 4 and 5: Positioning the user about the interaction with the product from the specific mode.

4 - What was the degree of difficulty for you to identify the product?

Extremely difficult - Extremely easy (semantic differential scale from a $10 \mathrm{~cm}$ line with no visual reference).
5- How does your ultimate experience of the stimuli help you to understand the use of this product?

This stimulus does not influence me at all or this stimulus strongly influenced me. (semantic differential scale from a $10 \mathrm{~cm}$ line with no visual reference).

If it influence you - Negatively influences influences strongly (semantic differential scale from a $10 \mathrm{~cm}$ line with no visual reference).

Next, participants were asked to indicate "yes" or "no" to the comments made. As shown in Table 4. The recognition of the product (total) was an indicator for the four statements from the unimodal interaction.

Table 4

Example of structure for data collection/general

\begin{tabular}{|l|l|l|l|l|}
\hline Yes & No & Comments & $\begin{array}{l}\text { Sign (s) } \\
\text { on the } \\
\text { product }\end{array}$ & Categories \\
\hline & $\begin{array}{l}\text { Consider the } \\
\text { products that } \\
\text { interact is very } \\
\text { small compared to } \\
\text { my hand. }\end{array}$ & Size \\
\hline & $\begin{array}{l}\text { I find the product } \\
\text { that interacted is } \\
\text { apparently less } \\
\text { potent than a } \\
\text { motorcycle. }\end{array}$ & $\begin{array}{l}\text { Potency } \\
\text { product is light } \\
\text { interacted less than } \\
\text { a pound. }\end{array}$ & $\begin{array}{l}\text { I believe that the } \\
\text { product is powered } \\
\text { interacted. }\end{array}$ & \\
\hline & & Operation \\
\hline
\end{tabular}

SOURCE: Author (2011).

Evaluation - step 1

Questions 1 and 2: Qualitative assessment from a categorization of responses.

Question 3-Assessment post-test:

( ) Identification total (2 points)

( ) Identification partially (1 point)

( ) Incorrect identification (any aspect)

Questions 4 and 5: Quantitative assessment from the average of the results for the indicator Positioning on the user's interaction with the product from the specific mode. Four statements: Evaluation occurred from the binary "correct" and "Wrong". Each correct answer was valued in two points. The 
total of these points from these four responses were added to the score of question number three. The result was the input for the quantitative indicator recognition of the entire product from the unimodal interaction. The "evidence in the product" were categorized and analyzed qualitatively.

\section{Step 2: Specific}

Participants were asked to mark "yes" or "no" as a response to comments made. As an indicator for the four statements, we have the recognition of the specific product from the unimodal interaction. Here, we were indicate with an " $\mathrm{x}$ " the correct answers. As shown in Table 5.

\section{Stimulus: Tactile}

Table 5

Example of structure for data collection/ Tactile

\begin{tabular}{|l|l|l|l|}
\hline Yes & No & $\begin{array}{l}\text { Considerations } \\
\text { product. }\end{array}$ & Category \\
\hline & $\begin{array}{l}\text { Consider the product disk. } \\
\text { I consider the cold product, } \\
\text { compared to my body temperature }\end{array}$ & $\begin{array}{l}\text { Temperature } \\
\text { in use }\end{array}$ \\
\hline & $\begin{array}{l}\text { Consider the product heavier than } \\
\text { a kilo. }\end{array}$ & Weight \\
\hline & $\begin{array}{l}\text { I think the product has a more } \\
\text { straight. }\end{array}$ & Form \\
\hline & $\begin{array}{l}\text { I think this product is difficult to } \\
\text { transport to a distance of greater } \\
\text { than } 10 \text { meters. }\end{array}$ & Transport \\
\hline
\end{tabular}

SOURCE: Author (2011).

\section{Stimulus: Hearing}

Here is repeated the same procedure as the table 4, and 5, where the correct answers were presented in green and incorrect answers were presented in red.

Table 6

Example of structure for data collection/hearing

\begin{tabular}{|l|l|l|l|}
\hline Yes & No & Considerations & Category \\
\hline & $\begin{array}{l}\text { I believe that the product is an } \\
\text { approximation. }\end{array}$ & sound type \\
\hline $\begin{array}{l}\text { I believe that the product } \\
\text { produces noise instead of a voice } \\
\text { recording. }\end{array}$ & sound type \\
\hline & $\begin{array}{l}\text { The product is with the touch of } \\
\text { just one command. (ie. on } \mid \text { off) }\end{array}$ & stages of use \\
\hline & $\begin{array}{l}\text { the sound produced by the } \\
\text { product is associated with the }\end{array}$ & sound \\
\hline
\end{tabular}

\begin{tabular}{|l|l|l|l|}
\hline & $\begin{array}{l}\text { different functions of use. (eg a } \\
\text { washing machine has the } \\
\text { following functions use: wash, } \\
\text { rinse and spin) }\end{array}$ & association \\
\hline & $\begin{array}{l}\text { need to use the product in direct } \\
\text { contact with the subject }\end{array}$ & interaction \\
\hline
\end{tabular}

SOURCE: Author (2011).

Estímulo: Visão

Table 7

Example of structure for data collection/Vision

\begin{tabular}{|l|l|l|l|}
\hline Yes & No & Considerations & Category \\
\hline & & the product has a straight form. & form \\
\hline & & $\begin{array}{l}\text { the product is lighter than a kilo. } \\
\text { the product is rigid. }\end{array}$ & $\begin{array}{l}\text { pheight } \\
\text { property }\end{array}$ \\
\hline & $\begin{array}{l}\text { the product is associated with (s) } \\
\text { (s) to function (s). }\end{array}$ & $\begin{array}{l}\text { form associa- } \\
\text { tion }\end{array}$ \\
\hline & $\begin{array}{l}\text { the product does not provide } \\
\text { direct contact in the subject. }\end{array}$ & interaction \\
\hline $\begin{array}{l}\text { the product is difficult to } \\
\text { transport to a distance of greater } \\
\text { than 10 meters. }\end{array}$ & Transport \\
\hline
\end{tabular}

SOURCE: Author (2011).

Evaluation

of

stage

2

For assessments relating to touch and vision, every consideration right correspond to 1.67 points. Thus, the sum of six correct considerations will total 10 points. Regarding the hearing, each account correctly correspond to 2.0. Thus, the sum of the five considerations also will total 10 points.

\section{Step 3: Final}

At this stage the participants on experience related product functionality. To this end, the subjects chose the alternative that best-tions related to the product. From the interaction with the product, you would conclude that the product is for ... [Adapted from Sonneveld and Schifferstein (2008)].

( ) Play

( ) Use

( ) Lead $\backslash$ port

( ) Care

( ) Explore

( ) Other

Evaluation of step 3

The data will be correlated more of the categories 
mentioned in the different modalities of sensory stimuli.

\section{Considerations}

In this experiment has been verified as the sensory stimuli can influence the general recognition of the product and on its own merits. However, this study analyzed the sensory stimuli separately. Thus, we identified this as a negative aspect, since, in most cases, we have a multi-sensory interaction with the product. On the positive side, we see the importance of considering the sensory stimuli in a product evaluation.

\section{Results}

As a results, we constructed a table 8 that illustrates an overview of the experiments. After building the table, we have identified these "procedures to be performed similar experiments in" inputs that can guide researchers. From the summary presented in the table 9 it was regarding the positive aspects to be considered in an experiment. And these points correlate with the procedures suggested for a similar experiment.

\section{Final considerations}

The paper presented a design stage of an experiment that has an emphasis on the following research question: how to assess the user friendliness of products in use? For this purpose, we developed three different approaches involving the use of products in intuitiveness. These approaches were in the scope of the search, however, were not designed to answer the research question. Among the procedures, it is important to consider the technology familiarity questionnaire in experiments that seek to evaluate the intuitiveness. It is from this that will identify if the participant already has a more advanced experience with the product or not. Two other aspects to be considered is the use of aspects to the intuitive use associated with the tasks, as well as consider the interaction from the sensory stimuli, not just vision. As future work, it is suggested that the procedures indicated in the text can be tested, and then transformed into guidelines for the construction of experiments within this scope. Another approach suggested is to use this scope for the development of research aimed also to graphic design.

Table 8 .

Synthesis experiments.

\begin{tabular}{|c|c|c|c|c|c|c|c|}
\hline 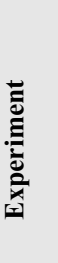 & 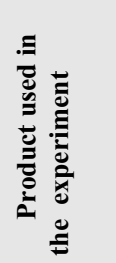 & 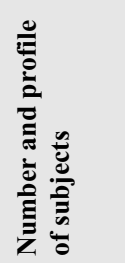 & 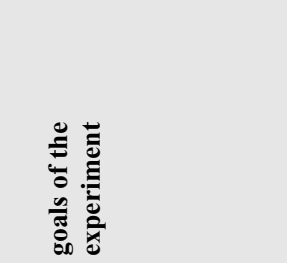 & 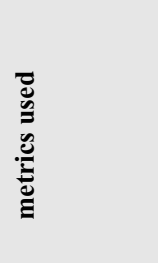 & 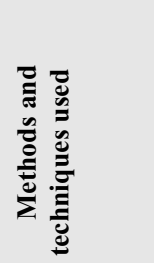 & 冚 & 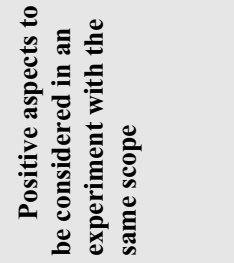 \\
\hline 1 & $\begin{array}{l}\text { Salify } \\
\text { Juice }\end{array}$ & $\begin{array}{l}20, \text { did } \\
\text { not know } \\
\text { the } \\
\text { product }\end{array}$ & $\begin{array}{l}\text { Check the recognition } \\
\text { of Salif Juicy with and } \\
\text { without the presentation } \\
\text { of the product. } \\
\text { Compare the trial of the } \\
\text { product before and after } \\
\text { use. }\end{array}$ & $\begin{array}{l}\text { Performance } \\
\text { metrics } \\
\text { (success of } \\
\text { the task and } \\
\text { errors) and } \\
\text { Self-report }\end{array}$ & $\begin{array}{l}\text { Observation } \\
\text { Thinking } \\
\text { aloud }\end{array}$ & Chi Square & $\begin{array}{l}\text { Identification of the } \\
\text { public unfamiliar } \\
\text { with the product } \\
\text { technology; } \\
\text { Treatment of the } \\
\text { data so mixed }\end{array}$ \\
\hline
\end{tabular}




\begin{tabular}{|c|c|c|c|c|c|c|}
\hline 3 & $\begin{array}{l}\text { vacuum } \\
\text { cleaner }\end{array}$ & $\begin{array}{l}30, \\
\text { random }\end{array}$ & $\begin{array}{l}\text { Comparison of different } \\
\text { modalities of sensory } \\
\text { stimuli. Identification of } \\
\text { the stimulus provided } \\
\text { the best product } \\
\text { knowledge. }\end{array}$ & $\begin{array}{l}\text { Performance } \\
\text { metrics } \\
\text { (success of } \\
\text { the task and } \\
\text { errors) }\end{array}$ & $\begin{array}{l}\text { Observation } \\
\text { Thinking } \\
\text { aloud }\end{array}$ & $\begin{array}{l}\text { Relationship } \\
\text { between sensory } \\
\text { stimuli and the } \\
\text { parties and } \mid \text { or } \\
\text { product functions. }\end{array}$ \\
\hline
\end{tabular}

Table 9

Positive Aspects and the procedures to be performed in the experiment

\begin{tabular}{|c|c|c|}
\hline Number & $\begin{array}{l}\text { Positive aspects identified in the } \\
\text { experiments }\end{array}$ & Procedures to be performed in a similar experiment \\
\hline 2 & Treatment of the data so mixed & construction and definition of the experiment. \\
\hline 4 & $\begin{array}{l}\text { Individual relationship between tasks and } \\
\text { the aspects that influence the } \\
\text { intuitiveness of use. }\end{array}$ & $\begin{array}{l}\text { Identify which aspects of intuitive use were considered for each task. } \\
\text { Then, evaluate not only the success of the task, but the successful } \\
\text { implementation of these aspects in the product. }\end{array}$ \\
\hline 5 & $\begin{array}{l}\text { Relationship between sensory stimuli } \\
\text { and the parties and } \mid \text { or product functions. }\end{array}$ & $\begin{array}{l}\text { To identify which sensory stimuli are associated with each task. Then, } \\
\text { evaluate the success of the use of less interaction with the product. }\end{array}$ \\
\hline
\end{tabular}

SOURCE: Author (2011).

\section{References}

[1] Cybis, W. A.; Bertiol, A. H.; Faust, R. (2007) Ergonomia e usabilidade: conhecimentos, métodos e aplicações. São Pau1o: Novatec Editora.

[2] Goldstein, E. B. (1989) Sensation and Perception. Pacific Grove, Califórnia: Books $\backslash$ Cole Publishing Company, third edition.

[3] Hutchins, E. (1999) Cognitive Artifacts. In Robert Wilson and Frank Keil (Eds.). The MIT Encyclopedia of the Cognitive Sciences. Cambridge: MIT Press.

[4] Iida, I. (2005) Ergonomia: projeto e produção. $2^{\mathrm{a}}$ edição. São Paulo: Editora Edgard Blücher.

[5] Jardim, S. R. (2002) Avaliação do conforto de ônibus urbano: estudo de caso no Distrito Federal. Dissertação de mestrado. Brasília: UnB.

[6] Jordan, W. Patrick. (1998) Human factors for pleasure in product use. In: Applied Ergonomics Vol 29, No. 1, (p. 25-33).

[7] Krippeendorff, K. (2006) The semantic turn. Boca Raton: Taylor \& Francis Group.

[8] Kwahk, J; Han, S. H. (2002) A methodology for evaluating the usability of audiovisual consumer electronic products. Applied Ergonomics 33 (p. 419-431).

[9] Lidwell, L.; Holden, K.; e Jill, B. (2010) Princípios Universais do Design. Porto Alegre: Bookman.

[10] Nielsen, J. (1993) Usability engineering. Boston: Academic Press.

[11] Null, R. I. (1993) Universal design directives for workplace. Anais do XII Congresso da Internacional Ergonomics Association. Toronto. V.3, (p. 211-212).

[12] Popovic, V; Chamorro-Koc, M,; Emmison, M. (2008) Using visual representation of concepts to explore users and design- ers' concepts of everyday products. In: Design Studies 29 Grã-Bretanha: Elsevier, 2008.

[13] Popovic, V.; Blackler, A.; Mahar, D. (2003) The nature of intuitive use of products: an experimental approach. In: Design Studies 24. Grã-Bretanha: Elsevier, (p. 491-509).

[14] Rutter, B. G.; Becka, A. M. e Jenkins, D. A. (1997) Usercentered approach to ergonomic seating: a case study. Design Management Journal Vol Spring (p. 27-33).

[15] Schifferstein, H. N. J.; Hekkert, P. (2008) Product Experience. Elsevier.

[16] Schifferstein, H. N. J.; Cleiren, M. P. H. D. (2005) Capturing product experiences: a split-modality approach. In: Acta Psychologica 118. Elsevier, (p. 293-318).

[17] Silva, C. M. AL; Okimoto, M. L. (2011) Considerando a intuição no uso de produtos. In: Anais do $11^{\circ}$ Congresso Internacional de Ergonomia e Usabilidade de interfaces humano-tecnologia: produtos, informações, ambiente construído e transporte, Manaus.

[18] Sudjic, D. (2010) A linguagem das coisas. Tradução de Adalgisa Campos da Silva. Rio de Janeiro: Intrínseca.

[19] Usability Net. (2010) Tools \& Methods: methods table. From: http:// www.usabolitynrt.org/tools/methods.html. Acessado em: 17 de agosto de 2010.

[20] Van Hout, M. (2004) Interactive Products and User Emotions. Dissertação de mestrado. Twente. 